\title{
Evaluation of Pump Capacity in Pancasila Pumping Station, Madiun City, East Java
}

\author{
Novi Andriany Teguh ${ }^{1, \text { a) }}$, Umboro Lasminto ${ }^{1}$, Anak Agung Ngurah Satria \\ Damarnegara $^{1}$ \& Mohamad Bagus Ansori ${ }^{1}$ \\ ${ }^{1)}$ Civil Engineering Department, Institut Teknologi Sepuluh Nopember (ITS), Surabaya, Indonesia.
}

Correspondent : ${ }^{a}$ andrianynovi@gmail.com

\begin{abstract}
Madiun River catchment area is widely known for flooding in the rainy season. There is an embankment built to prevent the flood from entering the city. With the existence of the embankment, pumps are required to discharge the rainwater from the urban drainage channel into the river. The pumps located in the pumping stations are spread across the Madiun City. Each pumping station has a different capacity and different catchment areas. Nevertheless, its capacity is not sufficient to discharge the water flowing from the drainage channel into the river without causing flood in the city. Hence, the evaluation of pump capacity is necessary. In this study, a case study of Pancasila Pumping Station as a pumping station with the biggest catchment area is taken. From the rainfall data, flood discharge in the inlet of the pumping station is calculated using a synthetic unit hydrograph of the Nakayasu method. The capacity of the pump will be evaluated using the resulted flood discharge, whether the capacity is sufficient or not. Furthermore, the necessary pump quantity, the pump capacity, the operational hours, and the volume storage needed will be calculated. The results are: maximum flood discharge with a return period of 10 years is $20.206 \mathrm{~m}^{3} / \mathrm{s}$, the existing pump capacity is only 1,000 litre per second while the required pump capacity is $5 \mathrm{~m}^{3} / \mathrm{s}$ with the quantity of two units, both operated in the same time for 8 hours and one unit is operated for the ninth hour, equipped with a storage volume of $102,017 \mathrm{~m}^{3}$. Thus, the addition of pump capacity is necessary.
\end{abstract}

Keyword: infrastructure management, Madiun, flood, pump capacity, storage, synthetic unit hydrograph.

\section{INTRODUCTION}

The facility is an important component of life. Facilities must be well managed throughout their lifetime to be able to work properly (Soemitro \& Suprayitno, 2018). Infrastructure Asset Management (IAM) is a program and knowledge to manage the infrastructure through its life cycle to be able to function sustainably well, economically, efficiently, effectively and in conformity with sustainable principle (green principle: social, economic, environmental) (Soemitro \& Suprayitno 2018; Suprayitno \& Soemitro 2018).

The Infrastructure Life Cycle is started from the Idea of Infrastructure Need, followed by Infrastructure Planning, Infrastructure Design, Infrastructure Construction. After the Infrastructure has been constructed, the Infrastructure then can be utilized, means operated and maintained. But, beforehand, the infrastructure needs to be certified and administrated for utilization, each time the infrastructure needs to be evaluated for developing annual infrastructure program. At a certain condition, the infrastructure can be disposed, if the infrastructure is no longer needed to serve the Served Region (Suprayitno \& Soemitro, 2019).

Infrastructure evaluation is about evaluating the infrastructure related to the operation, maintenance, the function performance, the evaluation result is needed to formulate the next 
infrastructure program on development, operation and maintenance (Suprayitno \& Soemitro, 2018).

Flood pump is one of the river's infrastructures. River infrastructure itself includes not only upstream infrastructures such as dam and reservoir, but also downstream infrastructures such as irrigation systems, hydropower, and industrial process. The river has many functions in various aspects. It becomes a primary drainage system in the certain catchment area which functions as water storage. Therefore, the river plays an important role in flood and inundation occurrences (Maulana, Suprayitno \& Soemitro, 2019).

The Madiun River is a river in East Java, Indonesia. It is the largest tributary of the Bengawan Solo River watershed which is the longest river in Java Island. Its name indicates that it passes through the major Madiun City. The Madiun River flood pump is not functioning properly, proofed by the occurrence of floods every rainy season, so an evaluation of pump capacity is necessary.

This study was conducted to improve the performance function of the Pancasila Pumping Station facility to overcome the flood caused by the drainage channel flood in Madiun City. Besides, this study also aims to advance the knowledge of management asset infrastructure and facility.

\section{RESEARCH METHOD}

This study was conducted by following these steps: background statement, research objective statement, research method, literature review, data collection, research analysis and finalized by conclusions.

\section{LITERATURE REVIEW}

\section{Log Pearson Type III Distribution}

The Log Pearson type III distribution, recommended by the U.S. Water Resources Council (USWRC) in 1967, and subsequently updated in 1975, 1977 and 1981 as the base method of flood frequency analysis in the United States, has been widely used in many parts of the world (Arora \& Singh, 1989).

Maximum design rainfall is the largest annual rainfall that may occur in an area within a certain return period. In this study, the calculation of the maximum design rainfall was using the Log Pearson III method with the consideration that this method is suitable for a variety of skewness coefficient and kurtosis coefficient. Moreover, this method is more flexible and can be used for all data distribution.

The Log-Pearson Type III distribution was developed as a statistical distribution to model the flood peak. Its use is justified by the fact that it has been found to yield good results in many applications, particularly for flood peak data (Chow et al., 1988).

The steps to calculate the design rainfall are as follows:

1. Change the maximum daily rainfall data into the logarithmic form.

2. Calculate the average of the logarithmic data with the equation:

$$
\overline{\log X}=\frac{\sum_{i=1}^{n} \log X_{i}}{n}
$$

3. Calculate the standard deviation $(\mathrm{S})$ with the equation:

$$
S=\sqrt{\frac{\sum_{i=1}^{n}\left(\log X_{i}-\overline{\log X}\right)^{2}}{n-1}}
$$

4. Calculate the coefficient of skewness (Cs) with the equation:

$$
C_{S}=\frac{n \sum_{i=1}^{n}\left(\log X_{i}-\overline{\log X}\right)^{3}}{(n-1)(n-2)\left(S^{3}\right)}
$$


5. Calculate the logarithm amount of $X_{T}$ according to the equation:

$$
\log X_{T}=\overline{\log X}+K_{T} . S
$$

Where $K_{T}$ is a function of Cs and recurrence interval, the values are listed in the following table.

Table 1. $\mathrm{K}_{\mathrm{T}}$ values for Pearson Type III distribution

\begin{tabular}{|c|c|c|c|c|c|c|}
\hline \multirow{3}{*}{ Cs } & \multicolumn{6}{|c|}{ Return Period (year) } \\
\hline & 2 & 5 & 10 & 25 & 50 & 100 \\
\hline & \multicolumn{6}{|c|}{$\mathbf{K}_{\mathbf{T}}$} \\
\hline 0.1 & -0.017 & 0.836 & 1.292 & 1.785 & 2.107 & 2.4 \\
\hline 0 & 0 & 0.842 & 1.282 & 1.751 & 2.054 & 2.326 \\
\hline
\end{tabular}

6. The amount of rainfall design is the anti-log of $\log X_{T}$

\section{The Rational Mononobe Method}

The Rational Method is adopted to calculate rainfall discharge because it can be used for relatively narrow drainage areas. There is no consensus regarding the upper limit of a small catchment, values ranging from 0.65 to $12.5 \mathrm{~km}^{2}$ have been quoted in the literature, the current trend is to use 1.3 to $2.5 \mathrm{~km}^{2}$ as the upper limit for the applicability of the rational method (Ponce, 1989). The general form of Rational equation is as follow.

$$
Q=\frac{1}{3.6} C I A
$$

On early 1976, Mononobe equation was introduced in Indonesia and become familiar with hydrology design for calculating rainfall intensity at any time (Priambodo et al., 2019). Rainfall intensity (I) express the amount of rainfall in a certain period, in units of $\mathrm{mm}$ per hour. The form of the equation is as follow.

$$
I=\frac{R_{24}}{24}\left(\frac{24}{t_{c}}\right)^{2 / 3}
$$

The primary input is the maximum daily rainfall data $\left(\mathrm{R}_{24}\right)$. In this study, the maximum rainfall used is ten years return period rainfall $\left(X_{T=10}\right)$ resulted from Log Pearson Type III method.

To estimate the design flood hydrograph with the unit hydrograph, it is necessary to know the distribution of hourly rainfall within a time interval. Because the observation data of rain distribution is not available, the modified Mononobe formula is used for the calculation. Based on Van Breen's research in Indonesia, especially in Java Island, rainfall is concentrated for 4 hours with a total rainfall of $90 \%$ of the total rainfall for 24 hours. The equation is used to estimate the distribution of hourly rainfall for $1 \mathrm{~mm}$ of rain.

$$
R_{T}=\frac{R_{24}}{t}\left(\frac{t}{T}\right)^{2 / 3}
$$

Where:

$\mathrm{R}_{\mathrm{T}} \quad=$ average rainfall intensity in $\mathrm{T}$ hour $(\mathrm{mm} /$ hour $)$

$\mathrm{R}_{24} \quad=$ effective rainfall in 1 day $(\mathrm{mm})$

$\mathrm{t} \quad=$ time of concentration (4 hours)

$\mathrm{T} \quad=$ time of rainfall (hour)

The percentage of average hourly rainfall intensity can be calculated using the formula below. 


$$
R_{t}=\left(T \cdot R_{T}\right)-\left((T-1) R_{T-1}\right)
$$

This percentage is multiplied by the net rainfall so that the distribution of the rain of every hour is obtained. Net rainfall is the total rainfall that resulted in direct runoff. This direct runoff consists of surface runoff and interflow (water that enters the thin layer below the surface of the soil with low permeability, which comes out again in a lower place and turns into surface runoff).

$$
R_{n}=\alpha \cdot X_{T}
$$

Where:

$$
\begin{array}{ll}
\mathrm{R}_{\mathrm{n}} & =\text { net rainfall }(\mathrm{mm}) \\
\alpha & =\text { coefficient } \\
\mathrm{X}_{\mathrm{T}} & =\text { rainfall intensity }(\mathrm{mm})
\end{array}
$$

\section{Nakayasu Synthetic Unit Hydrograph Method}

Nakayasu synthetic unit hydrograph method in the application at 32 watersheds in Java, Indonesia, shows the average $22 \%$ error of hydrograph's shape and $9 \%$ error of peak discharge (Safarina et al., 2011). Moreover, Nakayasu synthetic unit hydrograph method has been repeatedly applied in East Java, especially in the Brantas river watershed. Until now, the results were quite satisfying. The use of this method requires several characteristics of parameters as follows:

1. Duration from the beginning of the rain to the peak of the hydrograph (time of peak, $t_{p}$ )

2. Duration from the point of heavy rain to the centre of weight hydrograph (time lag, $\mathrm{t}_{\mathrm{g}}$ )

3. Hydrograph timeframe (time base of the hydrograph, $t_{b}$ )

4. Catchment area (A)

5. The longest length of the channel

6. Flow coefficient (C)

The formula of the Nakayasu synthetic unit hydrograph is:

$$
Q_{p}=\frac{A R_{o}}{3.6\left(0.3 T_{P}+T_{0.3}\right)}
$$

Where:

$\mathrm{Q}_{\mathrm{p}} \quad=$ Flood peak discharge $\left(\mathrm{m}^{3} / \mathrm{s}\right)$

$\mathrm{R}_{\mathrm{o}} \quad=$ unit rainfall $(\mathrm{mm})$

$\mathrm{T}_{\mathrm{p}} \quad=$ Time for reaching the peak discharge (hour)

$\mathrm{T}_{0,3}=$ Time required for a decrease in discharge, from the peak to $30 \%$ peak (hour)

A $\quad=$ Catchment area $\left(\mathrm{km}^{2}\right)$

To determine $\mathrm{T}_{\mathrm{p}}$ and $\mathrm{T}_{0,3}$, the approached formula is used as follows:

$$
\begin{aligned}
& T_{p}=t_{g}+0.8 t_{r} \\
& T_{0.3}=\alpha t_{g} \\
& t_{r}=0.5 \sim 1 t_{g}
\end{aligned}
$$

Where:

$t_{g}=$ Time from the beginning of rainfall to the peak flood discharge (hour)

$t_{r}=$ Duration of rainfall (hour)

$\alpha=$ Hydrograph parameter, with criteria as follow:

a. In the usual drainage area, $\alpha=2$

b. The ascending hydrograph section is slow, descending fast: $\alpha=1.5$

c. The ascending hydrograph section is fast, descending slow: $\alpha=3$ 
In calculating $t_{g}$, there are two conditions :

1. If the river length is below $15 \mathrm{~km}(\mathrm{~L}<15 \mathrm{~km})$ :

$$
t_{g}=0.21 L^{0.7}
$$

2. If the river length is above $15 \mathrm{~km}(\mathrm{~L}>15 \mathrm{~km})$ :

$$
t_{g}=0.40+0.058 L
$$

The equations for the hydrograph synthetic curve are divided into two parts:

1. The rising curve, where $0 \leq t \leq T_{p}$

$$
Q_{(t)}=Q_{p}\left[\frac{t}{T_{p}}\right]^{2.4}
$$

2. The falling curve

a. Where $T_{p} \leq t<T_{p}+T_{0.3}$

$Q_{(t)}=Q_{p} 0.3^{\frac{\left(t-T_{p}\right)}{T_{0.3}}}$

b. Where $\left(T_{p}+T_{0.3}\right) \leq t \leq\left(T_{p}+T_{0.3}+1.5 T_{0.3}\right)$

$Q_{(t)}=Q_{p} 0.3^{\frac{\left(t-T_{p}+0.5 T_{0.3}\right)}{1.5 T_{0.3}}}$

c. Where $t>\left(T_{p}+T_{0.3}+1.5 T_{0.3}\right)$

$Q_{(t)}=Q_{p} 0.3^{\frac{\left(t-T_{p}+0.5 T_{0.3}\right)}{2.0 T_{0.3}}}$

The above formulas are empirical, its application to a watershed must be preceded by a selection of suitable parameters $\alpha, T_{p}$, and rain distribution patterns to obtain a hydrograph pattern that matches the observed flood hydrograph.

Flood hydrograph is calculated with the following equation:

$$
Q_{(t)}=\sum_{i=1}^{n} U_{i} P_{n-(i-1)}
$$

Where :

$Q_{(t)} \quad=$ Flood Discharge at the t-hour

$U_{i} \quad=$ Ordinate unit hydrograph $(\mathrm{i}=1,2,3 \ldots \mathrm{n})$

$P_{n} \quad=$ Net rainfall for successive times $(\mathrm{n}=1,2, \ldots \mathrm{n})$

\section{The Mass Curve Method}

The mass curve has many useful applications in the design of storage capacity, such as determination of reservoir capacity, operations procedure, and flood routing (Bharali, 2015). A mass diagram is the plot of accumulated inflow (i.e. flood discharge) or outflow (i.e. pumping discharge) versus time. The procedure to construct such a diagram is as follows:

1. From the records, determine the hourly flood discharge $\left(\mathrm{Q}_{\text {flood }}\right)$ for all 24 hours for typical days (using data of 10 years return period Synthetic Unit Hydrograph).

2. Calculate and plot the cumulative inflow against time, and thus plot the mass curve of inflow.

$$
\begin{aligned}
& \Delta I_{1}=\frac{Q_{\text {flood } 1}+Q_{\text {flood } 0}}{2} \times \Delta t \times 3600 \\
& I_{1}=I_{0}+\Delta I_{1}
\end{aligned}
$$


3. Determine the pump capacity required $\left(\mathrm{Q}_{\text {pump }}\right)$ and the operational procedure. Calculate and plot the outflow against time.

$$
\begin{aligned}
& \Delta O_{1}=\frac{Q_{\text {pump } 1}+Q_{\text {pump } 0}}{2} x \Delta t \times 3600 \\
& O_{1}=O_{0}+\Delta O_{1}
\end{aligned}
$$

4. The maximum amount of water drawn from the storage is the difference between supply and demand volumes from the beginning of the dry season (Subramanya, 2008). Read the storage volume as the sum of the two maximum ordinates between inflow and outflow line.

$$
S=I-O
$$

5. Determine the maximum storage required.

\section{DATA COLLECTION}

Data collected in this study include not only secondary data, such as rainfall data and maps of the catchment area, but also primary data which are data earned from the field survey, such as pump capacity, pump quantity, and the conditions around the pumping station.

There are seven pumping stations in Madiun City, shown in Figure 1. Each has its catchment area. Pancasila pumping station has the biggest catchment area for $2.86 \mathrm{~km}^{2}$. From the survey which is done in November 2019, the condition of the channel around the pumping station and its mobile pump is shown in Figure 2.

The data on Table 2 are the maximum rainfall data from each year for 30 years which is used to estimate the flood discharge, assuming that water flowing on the channel is mostly coming from the rainfall. Meanwhile on Table 3 are the general hydrological data from Pancasila watershed which are used for the hydrological analysis. 


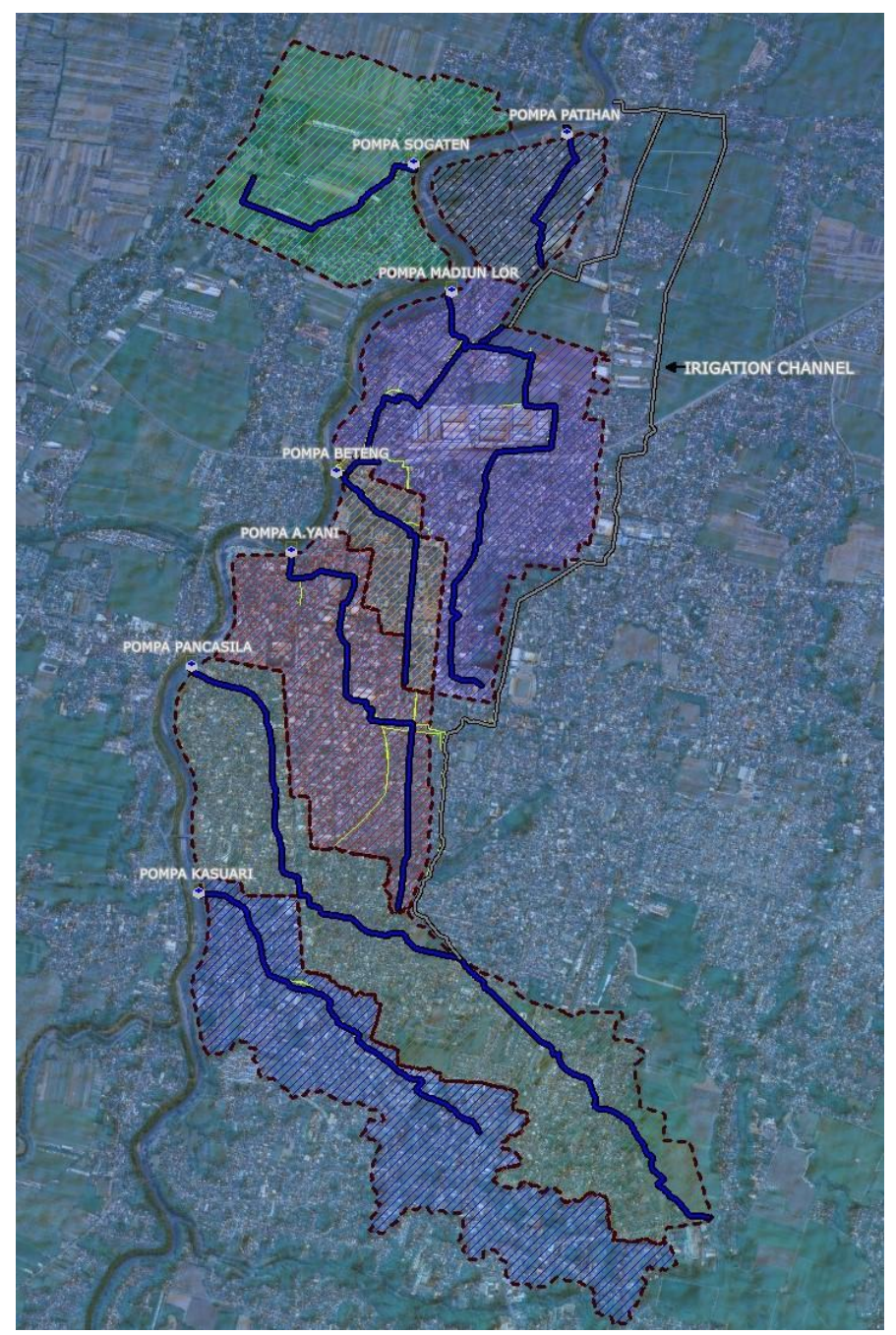

Figure 1. Pumping Stations Location in Madiun City

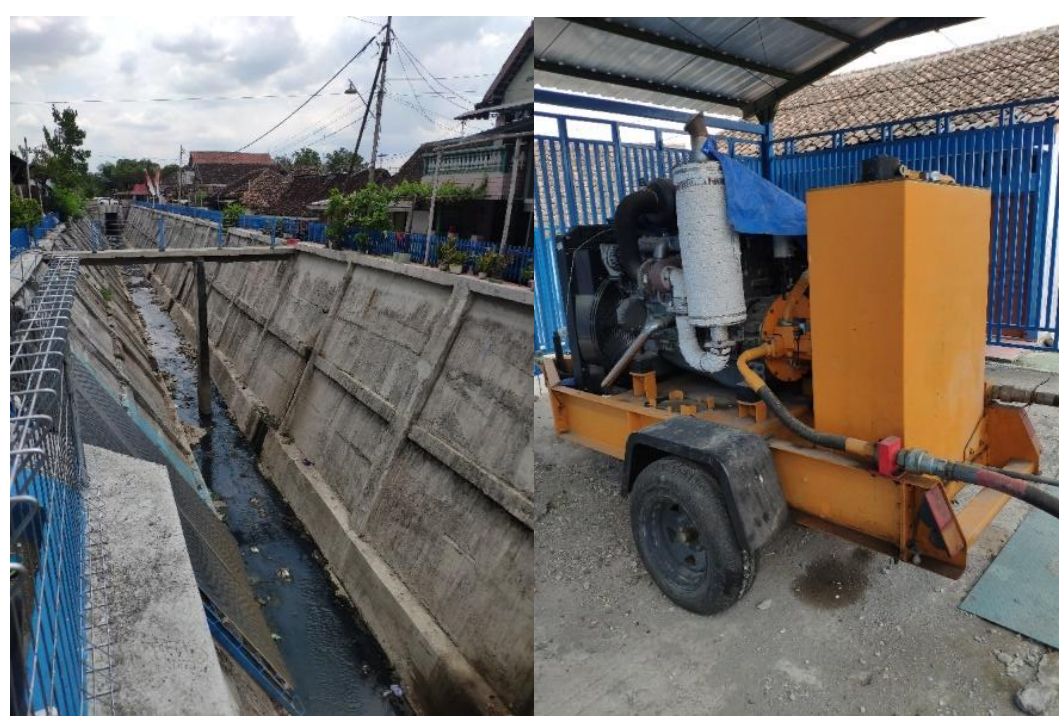

Figure 2. Channel (left) and Mobile Pump (right) in Pancasila pumping station 
Table 2. Maximum Rainfall Data Year 1976-2005

\begin{tabular}{cccccc}
\hline IYear & $\begin{array}{c}\text { Max. Rainfall } \\
(\mathbf{m m})\end{array}$ & Year & $\begin{array}{c}\text { Max. Rainfall } \\
(\mathbf{m m})\end{array}$ & Year & $\begin{array}{c}\text { Max. Rainfall } \\
(\mathbf{m m})\end{array}$ \\
\hline 1976 & 145 & 1986 & 83 & 1996 & 67 \\
1977 & 83 & 1987 & 95.5 & 1997 & 90.5 \\
1978 & 87 & 1988 & 96 & 1998 & 101.5 \\
1979 & 145 & 1989 & 94 & 1999 & 105 \\
1980 & 93.5 & 1990 & 99.5 & 2000 & 132.5 \\
1981 & 104 & 1991 & 103.5 & 2001 & 112.5 \\
1982 & 87 & 1992 & 107 & 2002 & 99.5 \\
1983 & 129 & 1993 & 115 & 2003 & 80.5 \\
1984 & 124 & 1994 & 117.5 & 2004 & 85 \\
1985 & 129 & 1995 & 96 & 2005 & 70 \\
\hline
\end{tabular}

Table 3. Hydrological Data for Analysis

\begin{tabular}{lll}
\hline Parameter & Unit & Data \\
\hline Name of watershed & - & Pancasila \\
River length & $\mathrm{km}$ & 5.16 \\
River flow velocity & $\mathrm{km} /$ hour & 1.832 \\
Time of concentration (Tc) & hour & 2.815 \\
Coefficient, $\alpha$ & - & 0.716 \\
Catchment area (A) & $\mathrm{km}^{2}$ & 2.86 \\
Upstream elevation (H1) & $\mathrm{m}$ & 79.816 \\
Downstream elevation $(\mathrm{H} 2)$ & $\mathrm{m}$ & 68.449 \\
River slope (I) & - & 0.002 \\
Existing pump capacity & litre/s & 1000 \\
\hline
\end{tabular}

\section{RESEARCH ANALYSIS}

\section{Estimating Maximum Design Rainfall}

The design rainfall for a watershed is obtained from the rainfall data from the Madiun rain gauge station in 30 years (1976-2005). Rainfall data used in the estimation of design rainfall is daily maximum rainfall data. It is selected annually for the highest rainfall event.

Log Pearson Type III is used as the method to estimate the design rainfall. From the distribution data analysis using Chi-Square test and the Smirnov-Kolmogorov test, it was found that the suitable results were given from the Log Pearson Type III method.

With the average of the logarithmic data $(\overline{\log X})$ of 2.003, a standard deviation of 0.084 and Cs value of 0.045 , the following table shows the calculation of maximum design rainfall for the return period of 2, 5, 10, 25, 50, and 100 years. For 10 years return period, the maximum design rainfall is $129.296 \mathrm{~mm}$.

Table 4. Design Rainfall for Various Return Period

\begin{tabular}{cccc}
\hline T (year) & K T & $\log \mathbf{X}_{\mathbf{T}}$ & $\mathbf{X T}_{\mathbf{T}}(\mathbf{m m})$ \\
\hline 2 & -0.008 & 2.003 & 100.581 \\
5 & 0.839 & 2.074 & 118.548 \\
10 & 1.286 & 2.112 & 129.296 \\
25 & 1.766 & 2.152 & 141.912 \\
50 & 2.078 & 2.178 & 150.756 \\
100 & 2.359 & 2.202 & 159.218 \\
\hline
\end{tabular}




\section{Estimating the Discharge due to Rainfall}

Calculating the rainfall intensity using Mononobe Method and the discharge using the Rational Method (return period of 10 years)

$$
\begin{aligned}
& I=\frac{R_{24}}{24}\left(\frac{24}{t_{c}}\right)^{2 / 3}=\frac{129.296}{24}\left(\frac{24}{2.815}\right)^{2 / 3}=22.48 \mathrm{~mm} / \text { hour } \\
& Q=\frac{1}{3.6} C I A=\frac{1}{3.6} \times 0.716 \times 22.48 \times 2.86=12.80 \mathrm{~m}^{3} / \mathrm{s}
\end{aligned}
$$

Determining the hourly rainfall distribution based on eq. (7) and eq. (8), then calculate the net rainfall using eq. (9). The results are shown on the table below.

Table 5. Hourly Rainfall Distribution

\begin{tabular}{ccc}
\hline $\begin{array}{c}\mathbf{t} \\
(\mathbf{j a m})\end{array}$ & $\mathbf{R t}(\boldsymbol{\%})$ & $\begin{array}{c}\text { Rt x Rn } \\
(\mathbf{m m})\end{array}$ \\
\hline 1 & $62.996 \%$ & 58.363 \\
2 & $16.374 \%$ & 15.170 \\
3 & $11.486 \%$ & 10.641 \\
4 & $9.144 \%$ & 8.471 \\
\hline & $100 \%$ & 92.645 \\
\hline
\end{tabular}

\section{Determining Synthetic Unit Hydrograph (SUH) using Nakayasu Method}

Before determining the synthetic unit hydrograph, the crucial times are necessary to be calculated. Using eq. (11) until eq. (14), the time parameters are defined and shown on the table below. 
Table 6. Time Parameter for Nakayasu Method

\begin{tabular}{lc}
\hline \multicolumn{1}{c}{ Parameter } & $\begin{array}{c}\text { Time } \\
\text { (hour) }\end{array}$ \\
\hline $\mathrm{Tg}$ & 0.662 \\
$\mathrm{Tr}$ & 1.000 \\
$\mathrm{Tp}$ & 1.462 \\
$\mathrm{~T} 0.3$ & 1.987 \\
$\mathrm{Tp}+\mathrm{T} 0.3$ & 3.449 \\
$\mathrm{Tp}+\mathrm{T} 0.3+1.5 \mathrm{~T} 0.3$ & 6.430 \\
$\mathrm{Tp}+\mathrm{T} 0.3+1.5 \mathrm{~T} 0.3+2 \mathrm{~T} 0.3$ & 10.404 \\
\hline
\end{tabular}

Determining the synthetic unit hydrograph based on the time parameters above. After that, hourly rainfall can be calculated. The flood discharge can be estimated while the baseflow is assumed to be zero. The result is shown in the following table and figure.

Table 7. Flood Discharge based on Nakayasu SUH

\begin{tabular}{|c|c|c|c|c|c|c|}
\hline \multirow[t]{2}{*}{$\begin{array}{l}\text { Time } \\
\text { (hour) }\end{array}$} & \multirow{2}{*}{$\begin{array}{c}\text { Unit } \\
\text { Hydrograph }\end{array}$} & \multicolumn{4}{|c|}{ Hourly Net Rainfall } & \multirow{2}{*}{$\begin{array}{c}\text { Discharge } \\
\mathbf{m}^{3} / \mathbf{s}\end{array}$} \\
\hline & & 58.363 & 15.170 & 10.641 & 8.471 & \\
\hline 0 & 0 & 0 & & & & 0 \\
\hline 1 & 0.125925 & 7.349 & 0 & & & 7.349 \\
\hline 1.462 & 0.313488 & 18.296 & 1.910 & 0 & & 20.206 \\
\hline 2 & 0.226325 & 13.209 & 4.756 & 1.340 & 0 & 19.304 \\
\hline 3 & 0.123475 & 7.206 & 3.433 & 3.336 & 1.067 & 15.042 \\
\hline 4 & 0.075289 & 4.394 & 1.873 & 2.408 & 2.656 & 11.331 \\
\hline 5 & 0.050269 & 2.934 & 1.142 & 1.314 & 1.917 & 7.307 \\
\hline 6 & 0.033563 & 1.959 & 0.763 & 0.801 & 1.046 & 4.569 \\
\hline 7 & 0.023738 & 1.385 & 0.509 & 0.535 & 0.638 & 3.067 \\
\hline 8 & 0.017533 & 1.023 & 0.360 & 0.357 & 0.426 & 2.166 \\
\hline 9 & 0.012951 & 0.756 & 0.266 & 0.253 & 0.284 & 1.559 \\
\hline 10 & 0.009566 & 0.558 & 0.196 & 0.187 & 0.201 & 1.142 \\
\hline 11 & 0.007065 & 0.412 & 0.145 & 0.138 & 0.149 & 0.844 \\
\hline 12 & 0.005219 & 0.305 & 0.107 & 0.102 & 0.110 & 0.623 \\
\hline 13 & 0.003855 & 0.225 & 0.079 & 0.075 & 0.081 & 0.460 \\
\hline 14 & 0.002847 & 0.166 & 0.058 & 0.056 & 0.060 & 0.340 \\
\hline 15 & 0.002103 & 0.123 & 0.043 & 0.041 & 0.044 & 0.251 \\
\hline 16 & 0.001553 & 0.091 & 0.032 & 0.030 & 0.033 & 0.186 \\
\hline 17 & 0.001147 & 0.067 & 0.024 & 0.022 & 0.024 & 0.137 \\
\hline 18 & 0.000847 & 0.049 & 0.017 & 0.017 & 0.018 & 0.101 \\
\hline 19 & 0.000626 & 0.037 & 0.013 & 0.012 & 0.013 & 0.075 \\
\hline 20 & 0.000462 & 0.027 & 0.009 & 0.009 & 0.010 & 0.055 \\
\hline 21 & 0.000341 & 0.020 & 0.007 & 0.007 & 0.007 & 0.041 \\
\hline 22 & 0.000252 & 0.015 & 0.005 & 0.005 & 0.005 & 0.030 \\
\hline \multirow[t]{2}{*}{23} & 0.000186 & 0.011 & 0.004 & 0.004 & 0.004 & 0.022 \\
\hline & & & & & Maximum & 20.206 \\
\hline
\end{tabular}




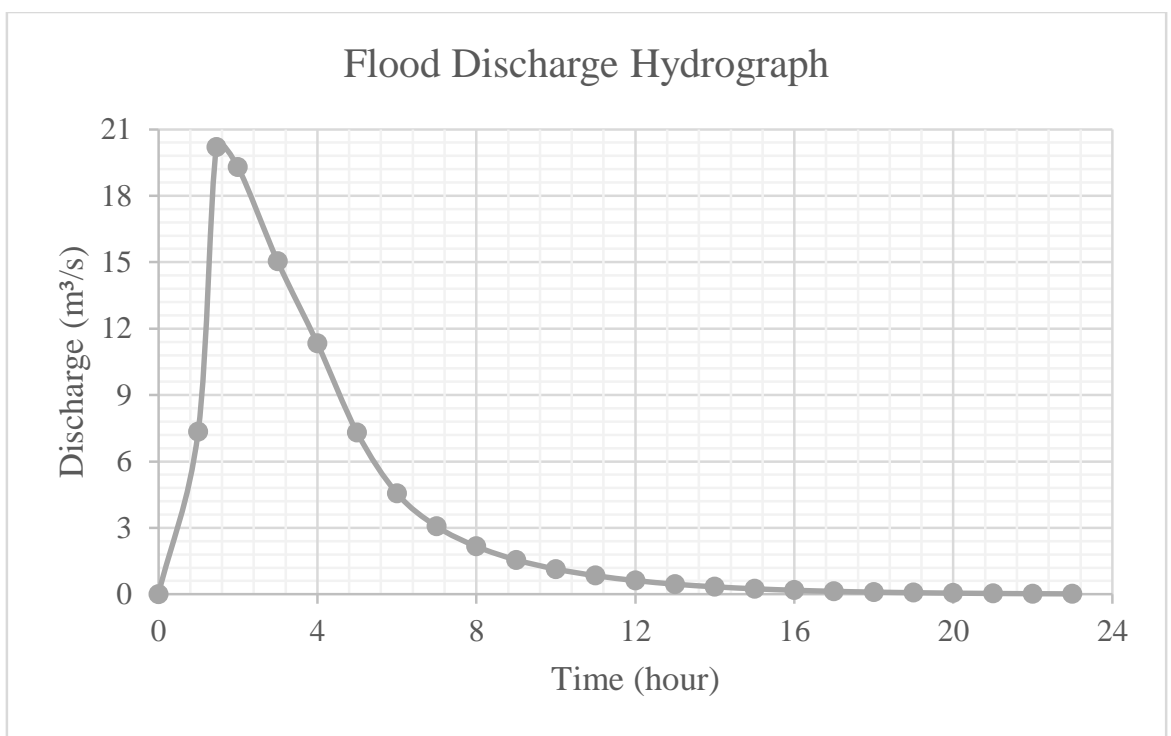

Figure 3. Flood Discharge Hydrograph

\section{Determining the Required Pump Capacity and Storage Volume}

The objective of this study is evaluating the pump capacity to improve its performance during the flood event. The existing pump capacity is $1000 \mathrm{l} / \mathrm{s}$ or $1 \mathrm{~m}^{3} / \mathrm{s}$, while the required pump capacity is more than that. Calculation of the pump capacity and the operation scheme of the pump are all based on the flood discharge as inflow with an assumption that the baseflow is zero. The outflow is the volume of the water pumped. Determining the storage needed can be done by calculating the difference between inflow and outflow, if the outflow is greater than inflow then the storage needed is zero. Trials and errors are performed to get the most efficient storage volume.

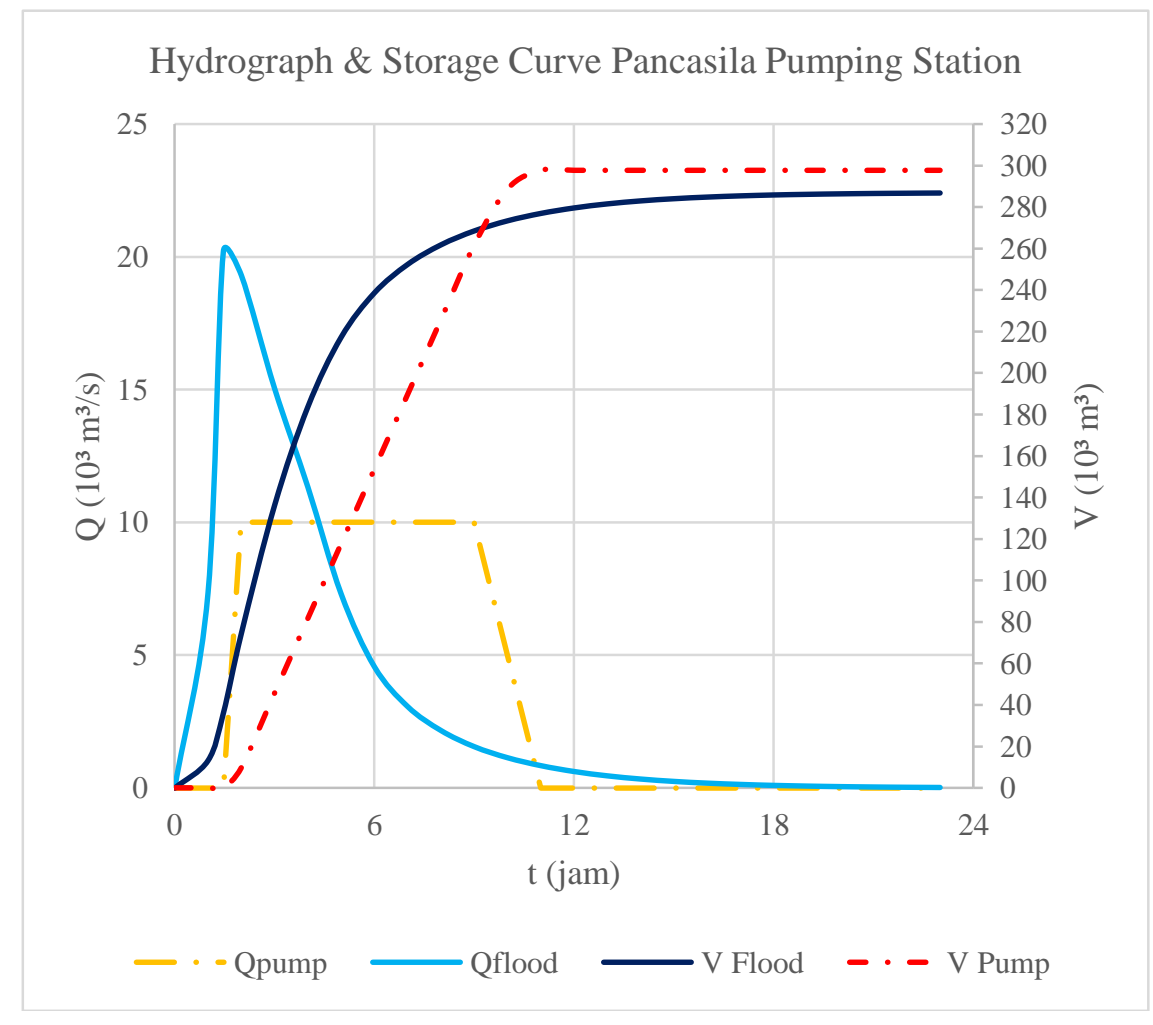

Figure 4. Hydrograph and Storage Curve 
Table 8. Pump Operation and Storage Volume Calculation

\begin{tabular}{|c|c|c|c|c|c|c|c|}
\hline Time (hour) & $\begin{array}{l}\text { Q10 } \\
\text { m }^{3} / \mathbf{s}\end{array}$ & $\begin{array}{c}\text { DV } \\
10^{3} \mathrm{~m}^{3} \\
\end{array}$ & $\begin{array}{l}\text { Inflow } \\
10^{3} \mathrm{~m}^{3} \\
\end{array}$ & $\begin{array}{c}\text { Qpump } \\
\text { m³/s }^{3}\end{array}$ & $\begin{array}{c}\text { DV } \\
10^{3} \mathrm{~m}^{3} \\
\end{array}$ & $\begin{array}{c}\text { Outflow } \\
10^{3} \mathrm{~m}^{3}\end{array}$ & $\begin{array}{c}\text { Storage } \\
10^{3} \mathrm{~m}^{3}\end{array}$ \\
\hline 0 & 0 & & 0 & 0 & & 0 & 0 \\
\hline 1 & 7.349 & 13.229 & 13.229 & 0 & 0 & 0 & 13.229 \\
\hline 1.462 & 20.206 & 22.932 & 36.160 & 0 & 0 & 0 & 36.160 \\
\hline 2 & 19.304 & 38.239 & 74.399 & 10 & 9.678 & 9.678 & 64.721 \\
\hline 3 & 15.042 & 61.824 & 136.223 & 10 & 36 & 45.678 & 90.545 \\
\hline 4 & 11.331 & 47.472 & 183.695 & 10 & 36 & 81.678 & 102.017 \\
\hline 5 & 7.307 & 33.549 & 217.244 & 10 & 36 & 117.678 & 99.566 \\
\hline 6 & 4.569 & 21.376 & 238.621 & 10 & 36 & 153.678 & 84.943 \\
\hline 7 & 3.067 & 13.745 & 252.365 & 10 & 36 & 189.678 & 62.687 \\
\hline 8 & 2.166 & 9.421 & 261.786 & 10 & 36 & 225.678 & 36.108 \\
\hline 9 & 1.559 & 6.705 & 268.491 & 10 & 36 & 261.678 & 6.813 \\
\hline 10 & 1.142 & 4.862 & 273.353 & 5 & 27 & 288.678 & 0 \\
\hline 11 & 0.844 & 3.575 & 276.928 & 0 & 9 & 297.678 & 0 \\
\hline 12 & 0.623 & 2.641 & 279.569 & 0 & 0 & 297.678 & 0 \\
\hline 13 & 0.460 & 1.950 & 281.519 & 0 & 0 & 297.678 & 0 \\
\hline 14 & 0.340 & 1.441 & 282.960 & 0 & 0 & 297.678 & 0 \\
\hline 15 & 0.251 & 1.064 & 284.024 & 0 & 0 & 297.678 & 0 \\
\hline 16 & 0.186 & 0.786 & 284.810 & 0 & 0 & 297.678 & 0 \\
\hline 17 & 0.137 & 0.581 & 285.391 & 0 & 0 & 297.678 & 0 \\
\hline 18 & 0.101 & 0.429 & 285.819 & 0 & 0 & 297.678 & 0 \\
\hline 19 & 0.075 & 0.317 & 286.136 & 0 & 0 & 297.678 & 0 \\
\hline 20 & 0.055 & 0.234 & 286.370 & 0 & 0 & 297.678 & 0 \\
\hline 21 & 0.041 & 0.173 & 286.543 & 0 & 0 & 297.678 & 0 \\
\hline 22 & 0.030 & 0.128 & 286.671 & 0 & 0 & 297.678 & 0 \\
\hline 23 & 0.022 & 0.094 & 286.765 & 0 & 0 & 297.678 & 0 \\
\hline \multicolumn{8}{|c|}{$\begin{array}{r}\text { Maximum Storage } \\
\left(10^{3} \mathrm{~m}^{3}\right) \\
\end{array}$} \\
\hline
\end{tabular}

\section{CONCLUSIONS}

This study concludes that the flood discharge with ten years return period calculated by the Nakayasu Method in the Pancasila watershed is $20.206 \mathrm{~m}^{3} / \mathrm{s}$. It is also estimated that the Pancasila watershed requires 2 units of pumps with the capacity of $5 \mathrm{~m}^{3} / \mathrm{s}$ each and a reservoir with a volume of $102,017 \mathrm{~m}^{3}$.

Considering the existing pump capacity which is only $1 \mathrm{~m}^{3} / \mathrm{s}$, the recommendation that can be given from this study is the necessity to increase the pump capacity at the Pancasila pumping house. Increasing the capacity of the pump must also be equipped with an adequate volume of storage. Furthermore, an additional capacity of floodgates is needed because the current floodgates are not sufficient.

\section{REFERENCES}

Arora, K. \& Singh, V.P. (1989). “A comparative evaluation of the estimators of the log Pearson type (LP) 3 distribution”. Journal of Hydrology (Elsevier) Volume 105, Issues 1-2, 30 January 1989, Pages 19-37. https://doi.org/10.1016/0022-1694(89)90094-2. 
Bharali, B. (2015). "Estimation of Reservoir Storage Capacity by using Residual Mass Curve". Journal of Civil Engineering and Environmental Technology, Volume 2, Number 10; April-June, 2015 pp. 15-18.

Chow, V. T., Maidment, D. R. \& Mays, L. W. (1988). Applied Hydrology. Austin, T.X. : McGraw-Hill, 1988.

Maulana, M. A., Suprayitno, H. \& Soemitro, R. A. A. (2019). "Preliminary Recognition of River Infrastructure”. Journal of Infrastructure \& Facility Asset Management - Vol. 1, Issue 1, March 2019.

Ponce, V. M. (1989). Engineering Hydrology: Principles and Practices. Englewood Cliffs, N.J. : Prentice-Hall, 1989.

Priambodo, S., Suhardjono, Montarcih, L. \& Suhartanto E. (2019). "Hourly rainfall distribution patterns in Java island". MATEC Web of Conferences 276, 04012. https://doi.org/10.1051/matecconf/201927604012

Safarina, A. B., Salim, H. T., Hadihardaja, I. K. \& Syahril, M. (2011). "Clusterization of Synthetic Unit Hydrograph Methods Based on Watershed Characteristics". International Journal of Civil and Environmental Engineering, 11(06), 2011, 76-85.

Soemitro, R. A. A. \& Suprayitno, H. (2018). "Preliminary Reflexion on Basic Concept of Facility Asset Management”. Jurnal Manajemen Aset Infrastruktur \& Fasilitas - Vol. 2, Sup. 1, Juni 2018.

Subramanya, K. (2008). Engineering Hydrology. New Delhi, India : Tata McGraw-Hill, 2008.

Suprayitno, H. \& Soemitro, R. A. A. (2018). "Preliminary Reflexion on Basic Principle of Infrastructure Asset Management". Jurnal Manajemen Aset Infrastruktur \& Fasilitas Vol. 2, No. 1, Maret 2018.

Suprayitno, H. \& Soemitro, R. A. A. (2019). "Reflection on Basic View of Public Infrastructure for Infrastructure Asset Management in Indonesia". Jurnal Manajemen Aset Infrastruktur \& Fasilitas - Vol. 3, Sup. 1, Juni 2019. 
e)ISSN 2656-8896 (p)ISSN 2656-890X

Journal of Infrastructure and Facility Asset Management - Vol. 2, Issue. 2, September 2020 